\title{
Pipe Stress and Turbine Nozzle Load Analysis for HP Steam Inlet and MP Steam Extraction on Turbine Generator 51G201T Capacity 10MW
}

\author{
Udin Komarudin*, Iftika Philo, Nia Nuraeni, Nissa Syifa Puspani \\ Mechanical Engineering Department, Widyatama University, Indonesia \\ *Corresponding authorE-mail: komarudin.mt@widyatama.ac.id
}

\begin{abstract}
Thermal pipe expansion on the turbine greatly affects the performance of the turbine, mainly produces misalignment in turbines. The stress analysis on the pipe and the load on the nozzle is very important to ensure that the stress that occurs is still safe and the load that occurs on the nozzle is still below the allowable load. Field information is known, Steam type of 51-G-201-T, capacity 10 MW, total weighs 58 tons, weight casing 37 tons, which has been operating since July 1989, has been occur misalignment on turbines. Stress pipe and load analysis of turbine nozzles on the turbine using software (Autopipe V8i Select Series 3 Edition by Bentley). In this perspective, calculation methodologies were developed in order to do quick analysis of the most common configurations, according to the codes ASME B31.1 (Piping Power). The results of the pipe stress analysis showed that the maximum sustained stress ratio occurred at point A39 (0.32), maximum displacement stress ratio at point A39 (0.97) and maximum hoop stress ratio at point A09 (0.44), all values below 1. This shows that the stress is still safe. The result of load analysis on the turbine casing is the direction $x=-880 \mathrm{~kg}, y=6246.4 \mathrm{~kg}, \mathrm{z}=-$ $3697.7 \mathrm{~kg}$, smaller than the weight of the 37 tones turbine casing, so misalignment is not caused by shifting the turbine casing.
\end{abstract}

Keywords: Thermal expansion, pipe, nozzle, stress, allowable load.

\section{Introduction}

Steam turbine is an energy conversion machine that changes the difference of pressure and temperature inlet and outlet, into mechanical energy in the form of shaft rotation. At high speed requires perfect shaft alignment and misalignment can cause high vibration, which results in damage to turbine components. In steam turbines, one of the causes of misalignment is the shift of the turbine casing, this is because the nozzles on the turbine casing cannot resistance pipe loads, especially thermal pipe loads [3]. So, it is very important to calculate the load that occurs to ensure nozzles are in a safe condition.

The first observation from the manufacturer of the turbine, said that there was no problem with the turbine, and temporary suspicion while the misalignment occurred due to a shift in the turbine casing caused by the load on the nozzle.

Field information is known, steam type of 51-G-201-T, capacity $10 \mathrm{MW}$, total weighs 58 tons, weight casing 37 tons, HP (High Pressure) steam inlet from Header to Turbine, operating temperature $460^{\circ} \mathrm{C}$, operating pressure $66 \mathrm{~kg} / \mathrm{cm}^{2}$, pipe diameter 14" and 16", material A335 P11, and MP (Middle Pressure) steam extraction line from Turbine to Header, operating temperature $330^{\circ} \mathrm{C}$, operating pressure $19 \mathrm{~kg} / \mathrm{cm}^{2}$, pipe diameter 14 " and 16", material A53-BS which has been operating since July 1989, has been occur misalignment on turbines.

Next observations in 2013, showed that there were no damage and shifts in turbine nozzles and casings. However, there has been occurs a shift in the pipe installation, as in the support of SH-51-001, the direction $\mathrm{z}=-15 \mathrm{~mm}, \mathrm{x}=+10 \mathrm{~mm}, \mathrm{y}=-10 \mathrm{~mm}$; support SH-51-002, direction $\mathrm{z}=-10 \mathrm{~mm}, \mathrm{x}=+30 \mathrm{~mm}, \mathrm{y}=-$ $10 \mathrm{~mm}$.

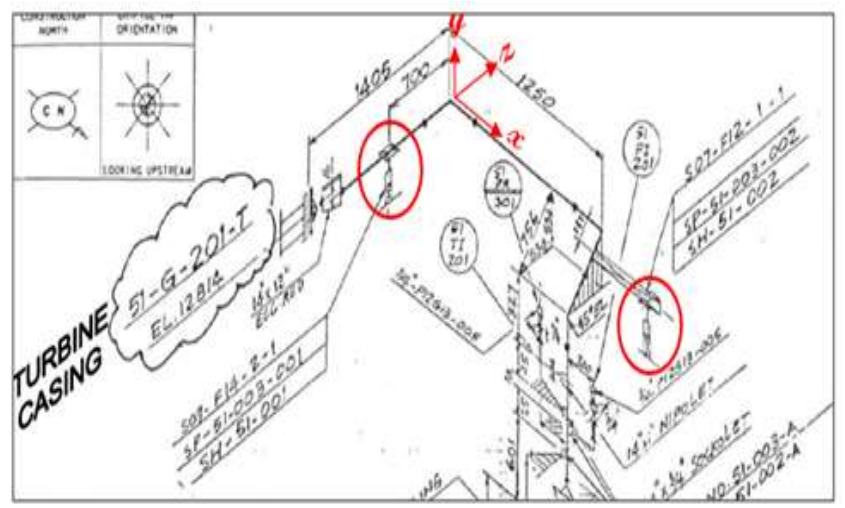

Fig. 1: Support SH-51-001 and SH-51-002

\section{Codes and Standard}

This standard code is the basic of engineer reference including design, testing, fabrication, installation and commissioning. In addition, there are also some codes that explain the reference for repair or maintenance. It only has one final goal, is safety.

Each scientific discipline has its own code. The basis of the development is based on several cases of previous accidents / problems. In general, the standard is a good and correct design requirement, while the code is a product of a standard institution that is adjusted to discipline and marked with certain codes. There are several 
standards used by engineers, including: ASME (American Society of Mechanical Engineers), API (American Petroleum Institute), ANSI (American National Standards Institute), ASTM (American Standard Testing and Material).

ASME is a committee that is concerned with the piping code. The pipe code is a code based on requirements that guarantees correct and safe operation in the piping system. The ASME B31-2010 code is a code for pressurized pipes consisting of several standard parts $[1,8]$.

- $\quad$ ASME B31.1, Power Piping

- $\quad$ ASME B31.3, Process Piping

- ASME B31.4, Piping line Transfortation System for liquid Hydrocarbons and other Liquid.

- ASME B31.5, Refrigeration Piping.

- $\quad$ ASME B31.8, Gas Transfortation and Distribution Piping System

- $\quad$ ASME B31.9, Building Services Piping.

- ASME B31.11, Slurry Transfortation Piping System.

In this study we use the ASME B31.1 code, Piping power. This code usually found in electric power stations, industrial and institutional plants, geothermal heating systems, central and district heating and cooling systems. The steam turbine is included in the ASME B31.1-2010 code (power piping).

\section{Thermal Expansion and Flexibility}

Most piping systems work at temperatures higher than the installation temperature. Temperature rise will cause thermal pipe expansion.

Thermal pipe expansion equation [1-3]:

$\Delta=\mathrm{L} .(\alpha)$

where $\Delta=$ Pipe Thermal expansion (in), $\mathrm{L}=$ Length pipe (ft) and $\alpha=$ Thermal expansion coefficient (in/100 ft).

The piping system must have sufficient flexibility, so that the pipe movement or support movement will not cause damage to the piping system.

The piping system must be designed according to the applicable code and meet flexibility requirements [7]:

- force calculation result must not damage the support, structure or connecting equipment.

- Pipeline displacement calculations must be in accordance with engineering limits.

Allowable stress range is stated in the ASME B31.1 (2010) power piping $[1,6-8]$ as follows:

$\sigma_{\mathrm{A}}=\mathrm{f}\left(1,25 \sigma_{\mathrm{c}}+0,25 \sigma_{\mathrm{h}}\right)$

where $\sigma_{c}=$ Allowable stress of pipe on ambient temperature during operation, $\sigma_{\mathrm{h}}=$ Allowable stress of pipe on high temperature during operation and $f=$ Stress reduction factor, which is the number of temperature cycles during operating life [1].

\section{Support System}

Support system modeling such as Spring, V-stop, Guide, Line Stop, Rotation, Damper, Tie / Link, Incline, anchor, are using modeling that is available in Autopipe software.

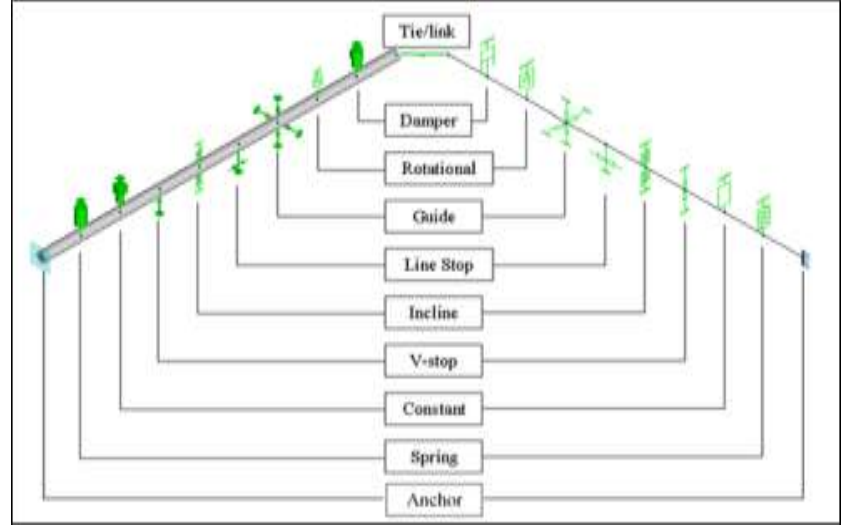

Fig. 2: Support system modeling [2]

\section{Results and Discussion}

The analysis was carried out to determine the pipe stress and turbine nozzle load, this is to answer the hypothesis from the turbine manufacturer.

There are two piping lines in this system:

- High Pressure (HP) Steam Inlet, from the Header - StrainerTurbine Casing.

- Extraction Line Middle Pressure (MP) Steam, from the Turbine Casing - Header.

Both pipelines have different data, so the analysis is carried out on each pipeline. Analysis of each pipeline is using Autopipe software, where there are three main section namely data input, process (running) and results.

\subsection{Data Parameter}

Table 1: Data parameters for HP Steam Inlet

\begin{tabular}{|c|c|c|}
\hline No. & Parameters & Value \\
\hline 1 & Operating Temperature & $460^{\circ} \mathrm{C}$ \\
\hline 2 & Operating Pressure & $60 \mathrm{~kg} / \mathrm{cm}^{2}$ \\
\hline 3 & Ambien Temperature & $37^{\circ} \mathrm{C}$ \\
\hline 4 & Pipe Diameter & $12^{\prime \prime}, 14^{\prime \prime}, 16^{\prime \prime}$ sch 120 \\
\hline 5 & Pipe material & A335P-11 \\
\hline
\end{tabular}

Table 2: Data parameters for Extraction Line Middle Pressure (MP) Steam

\begin{tabular}{|c|c|c|}
\hline No. & Parameters & Value \\
\hline 1 & Operating Temperature & $33^{\circ} \mathrm{C}$ \\
\hline 2 & Operating Pressure & $19 \mathrm{~kg} / \mathrm{cm}^{2}$ \\
\hline 3 & Ambien Temperature & $37^{\circ} \mathrm{C}$ \\
\hline 4 & Pipe Diameter & $14^{\prime \prime}, 16^{\prime \prime} \mathrm{sch} 120$ \\
\hline 5 & Pipe material & A53-B-S \\
\hline
\end{tabular}

Other data such as mild tolerance, insulation density, cold allowable, minimum yield, ultimate, long modulus, Hoop modulus, shear modulus, density, Poisson's ratio, will automatically be filled in by the software

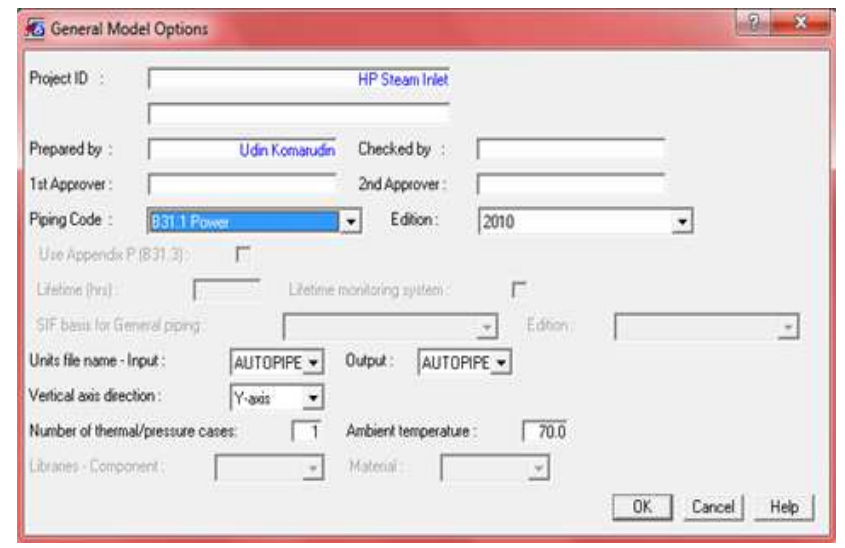

Fig. 3: Software application 
In this study, we use the ASME B31.1 code, Piping power.

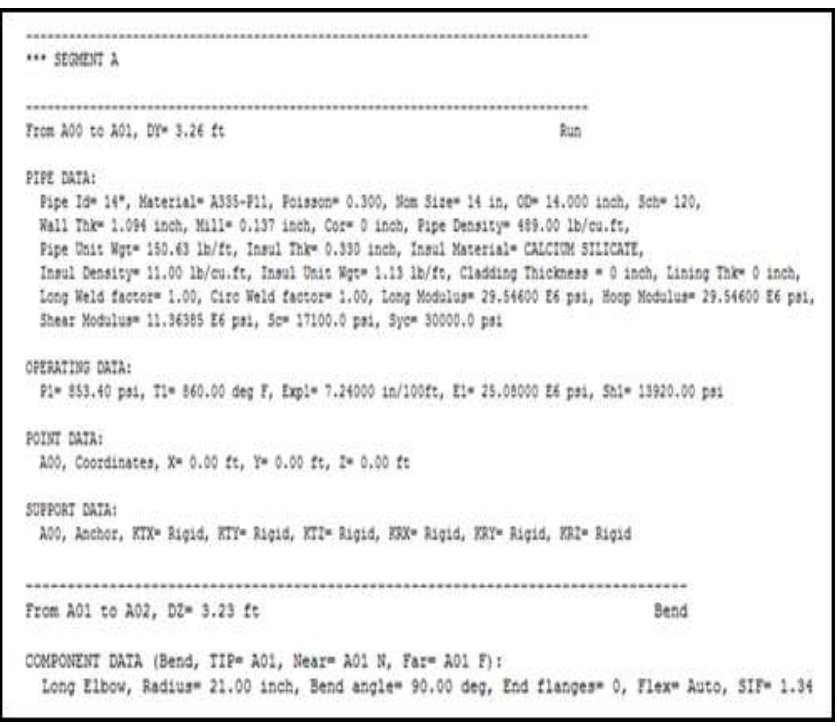

Fig. 4: Component Data Listing

\subsection{Modeling}

Modeling can be displayed after all pipe data parameters and isometric images have been inputted in the modeling dialog.

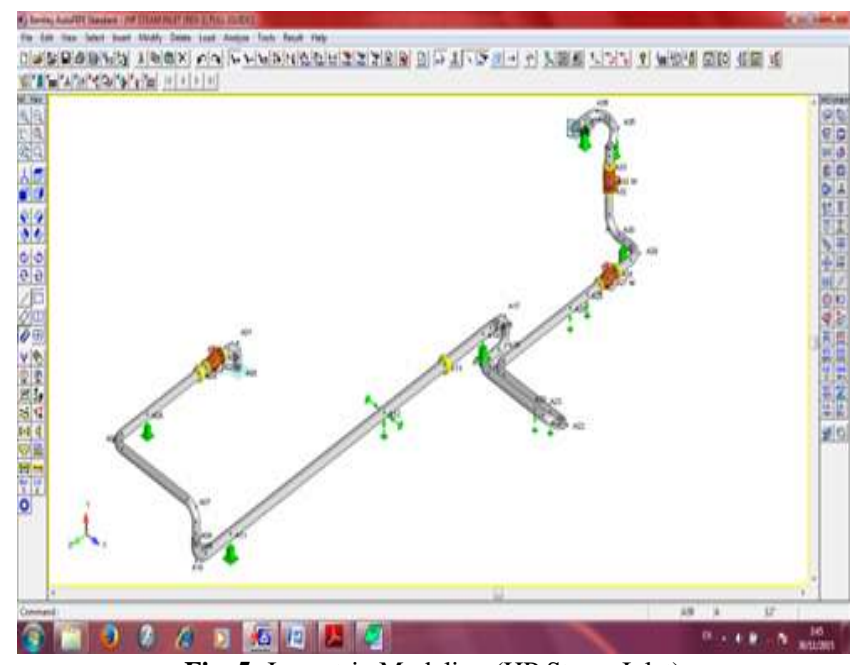

Fig. 5: Isometric Modeling (HP Steam Inlet)

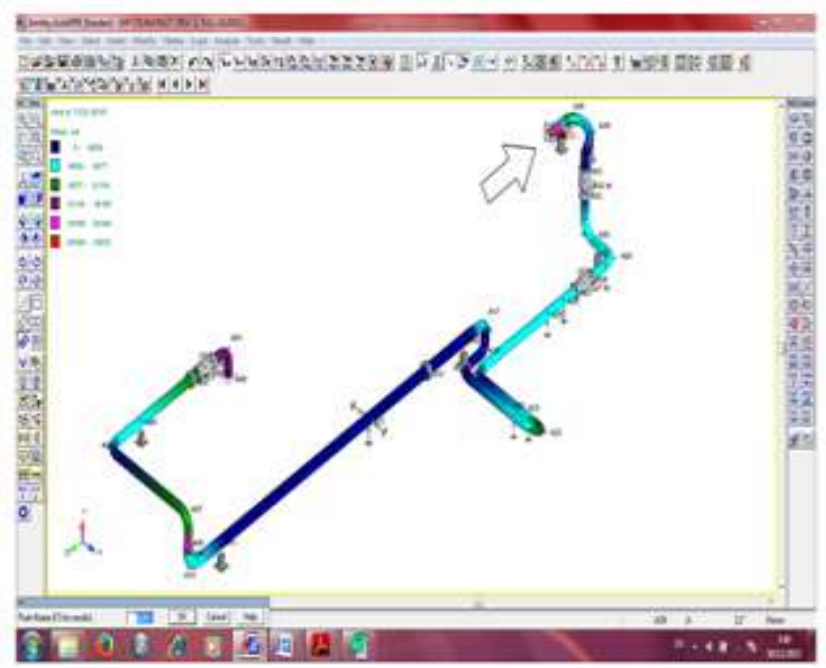

Fig. 6: Stress piping modeling (HP Steam Inlet)

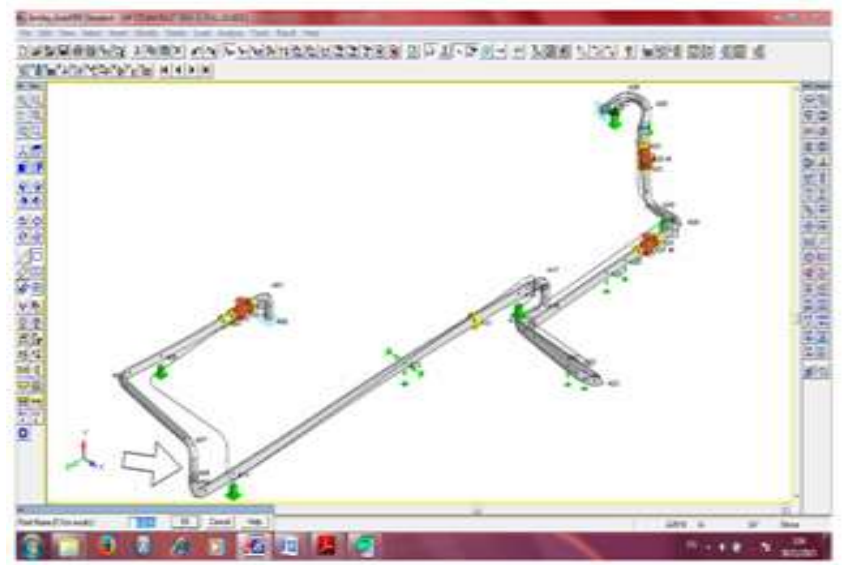

Fig. 7: Displacement modeling (HP Steam Inlet)

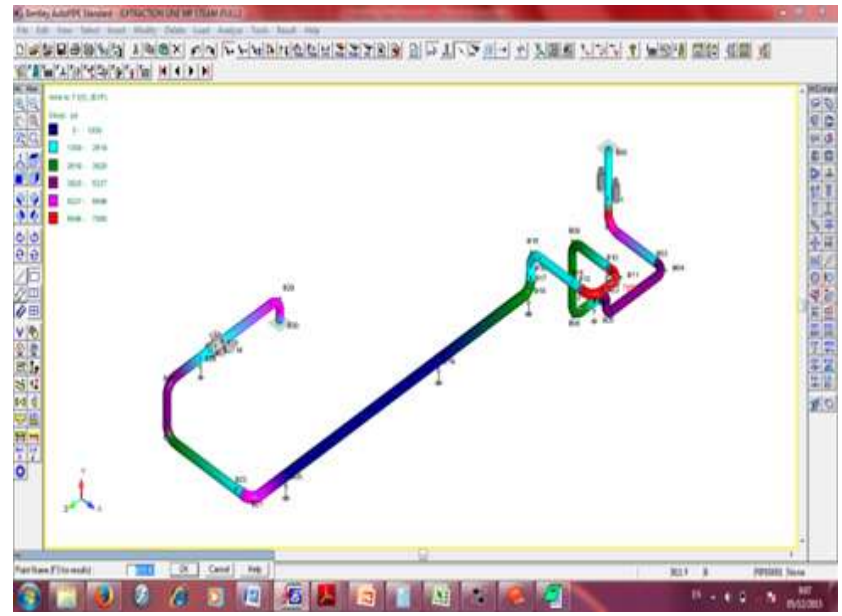

Fig. 8: Stress piping modeling (Extraction Line MP Steam)

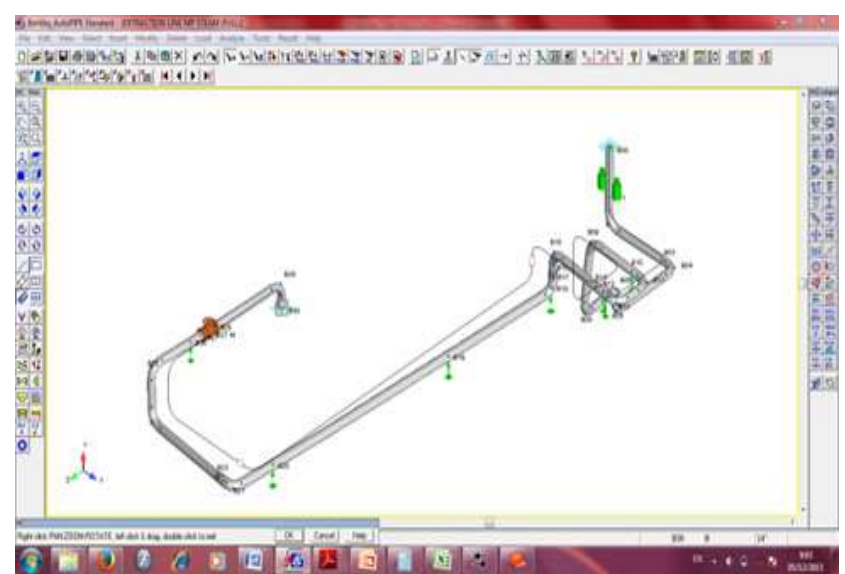

Fig. 9: Displacement modeling (Extraction Line MP Steam)

\subsection{Analysis Results}

Analysis results from Pipe Stress Analysis and Design Program, consisting of:

- Translation and rotation displacement at each point

- Support force such as V-stop, guide, spring can, line stop.

- Force and moments restrains reaction on anchors and support.

- Force and Global Moments at each point.

- Compliance with code B31.1-2010 namely SIF, code stress and code allowable.

- Summary of results consists of: max. displacements (in), max. rotations (deg), max restraint forces (lb), max restraint moments (ft.lb), max. pipe forces (lb), max. pipe moments (ft.lb), max sustained stress, max. stress displacement, max. stress hoop, max. sustained stress ratio, max displacement stress ratio, max hoop stress ratio. 

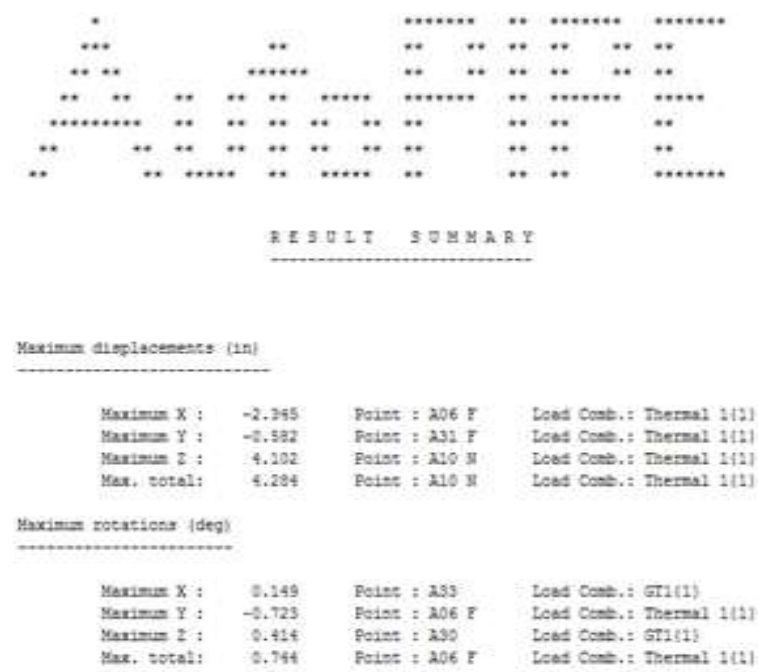

Maxima segtrain: forces (1D)

\begin{tabular}{|c|c|}
\hline Sasionse X; & 6394 \\
\hline Manise $Y:$ & -21453 \\
\hline $\begin{array}{l}\text { Marine z: } \\
\text { Yax, sotali: }\end{array}$ & 7207 \\
\hline
\end{tabular}

Foist : 212

Poist: : 236

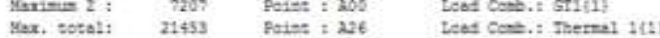

toos conb.: Thernsi liti

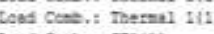

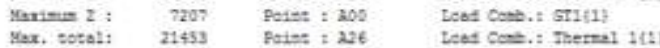

Muxina seotsatst moseors (tr-1b)

\begin{tabular}{|c|c|}
\hline & \\
\hline Nenistes Y: & -126457 \\
\hline 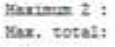 & $\begin{array}{r}71579 \\
137845\end{array}$ \\
\hline
\end{tabular}

Foise = 248 foint $: 200$ Fois: : $24:$

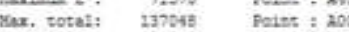

Leas Cont: : anis?

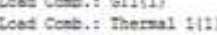
Soed cabs,: Grixt

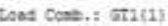

Maximur gustained stress

$$
\begin{array}{ll}
\text { Point } & =139 \\
\text { Stress pgi } & =4476 \\
\text { Allowable p9i } & =13920 \\
\text { Ratio } & =0.32 \\
\text { Load combination } & =\text { GR + Max P\{1\} }
\end{array}
$$

Vaxinum displacement grress

$$
\begin{array}{ll}
\text { Foint } & =\text { A39 } \\
\text { Stress pgi } & =24232 \\
\text { Allowable psi } & =24855 \\
\text { Ratio } & =0.97
\end{array}
$$$$
\text { Load combination : Nax Range }
$$

Vaximun hoop stress

$$
\begin{aligned}
\text { Foint } & =\text { A09 } \\
\text { Stress poi } & =6057 \\
\text { Allowable pai } & =13920 \\
\text { Ratio } & =0.44 \\
\text { Load combination } & =\text { Max F\{1\} }
\end{aligned}
$$

\begin{tabular}{|c|c|c|c|c|c|c|c|c|c|}
\hline Poitar & Lend & & Poncts & (dat & ) & & ONETHS is & $6.10)$ & \\
\hline$A n=n$ & seabltas:ien & $x$ & $y$ & 2 & Resuls & $x$ & $y$ & 2 & Resule \\
\hline & . & & & & & & & & \\
\hline & Wiethor fas $\mathrm{B}$ & & & & & & & & \\
\hline & Gaysty(2) & 0 & 1424 & 4 & 1924 & $96: 4$ & -26 & 2518 & 9939 \\
\hline & mertal :1!) & -2098 & 12556 & .7204 & $\$ 4627$ & 64494 & 99429 & 60052 & 10298! \\
\hline & ตร:(d) & -2092 & 19990 & -7207 & 25869 & $79: 08$ & 99999 & 71570 & $210990 !$ \\
\hline
\end{tabular}

Maximum sustained stress ratio

$$
\begin{array}{lll}
\text { Point } & : & \text { } 39 \\
\text { Stregs psi } & : 4476 \\
\text { Allowable psi } & : 13920 \\
\text { Ratio } & : & 0.32 \\
\text { Load combination } & \text { GR }+ \text { MaX P }\{1\}
\end{array}
$$

Maximum displacerent stress ratio

$$
\begin{array}{ll}
\text { Point } & \text { A } 39 \\
\text { Stress psi } & : 24232 \\
\text { Allowable psi } & : 24855 \\
\text { Ratio } & : 0.97 \\
\text { Load combination : } & \text { Max Range }
\end{array}
$$

Maximum hoop stregs ratio

$$
\begin{array}{ll}
\text { Point } & : \text { A09 } \\
\text { Stregs psi } & : 6057 \\
\text { Allowable psi } & : 13920 \\
\text { Ratio } & : 0.44 \\
\text { Load combination } & \text { : } \\
\text { Max P\{1\} }
\end{array}
$$

* The system satisfies ASME B31.1 (2010) code requirements : *

Fig. 10: Pipe Stress Analysis and Design Program

\subsection{Load Analysis on Nozzle, Turbine Casing}

The analysis results show that the Anchor load on the turbine casing (Node A40) as follows:

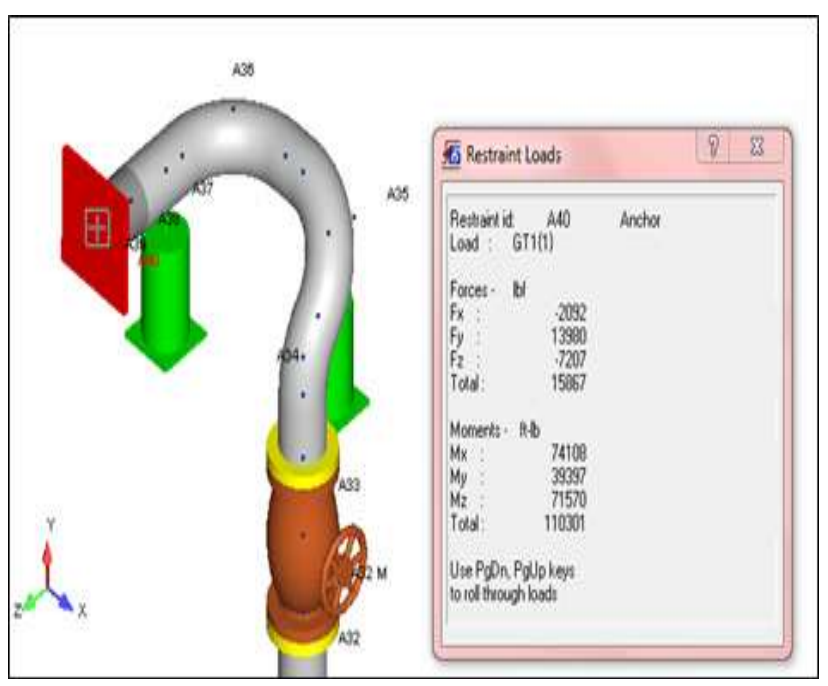

ALBTRALIIT RLACIIOHS

Fig. 11: Load Analysis

Maximum load on the anchor:

Force (lbf):

$$
\begin{aligned}
& F x=-2092 \text { (thermal and grafity) } \\
& F y=13980 \text { (thermal and grafity) } \\
& F z=-7207 \text { (thermal and grafity) }
\end{aligned}
$$

Moment (ft.lb):

$\mathrm{Mx}=74108$ (thermal and grafity)

My $=39397$ (thermal and grafity)

$\mathrm{Mz}=71570$ (thermal and grafity)

\subsection{Evaluation of Turbine Casing}

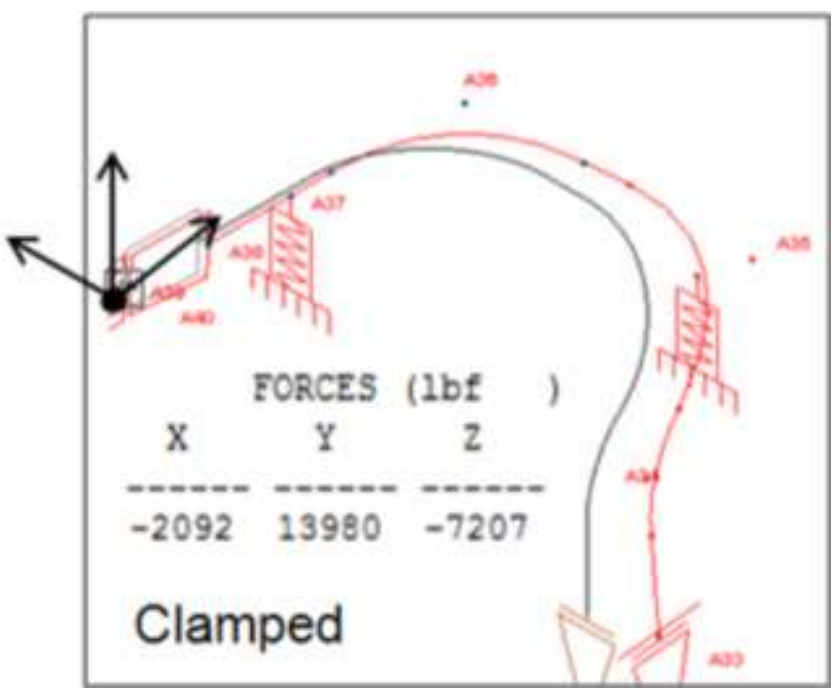

Fig. 12: HP Steam Inlet (clamped) 


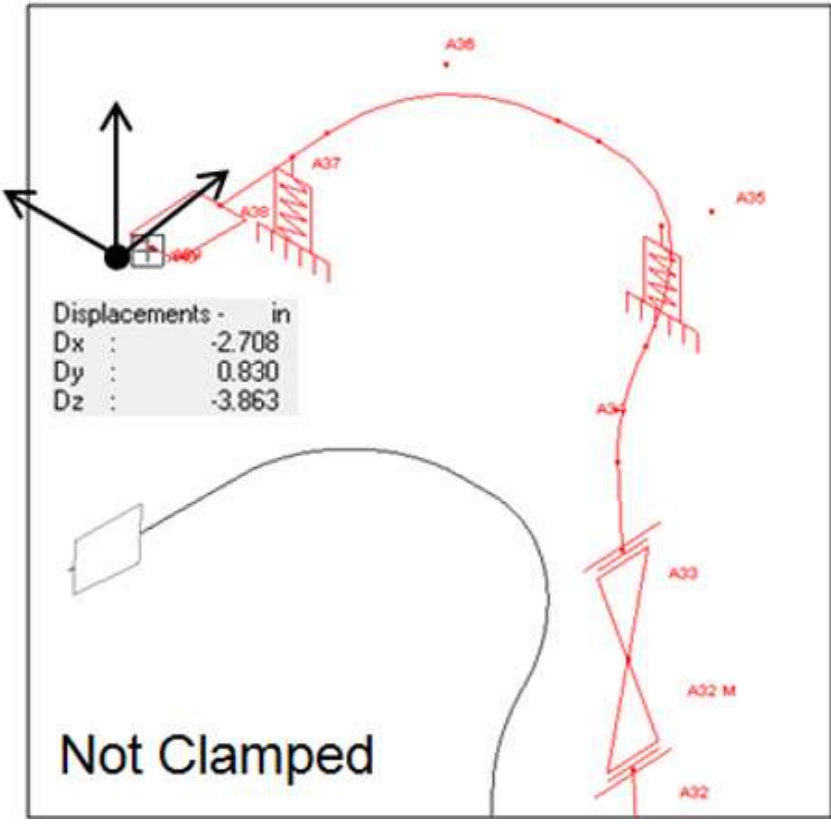

Fig. 13: HP Steam Inlet (not clamped)

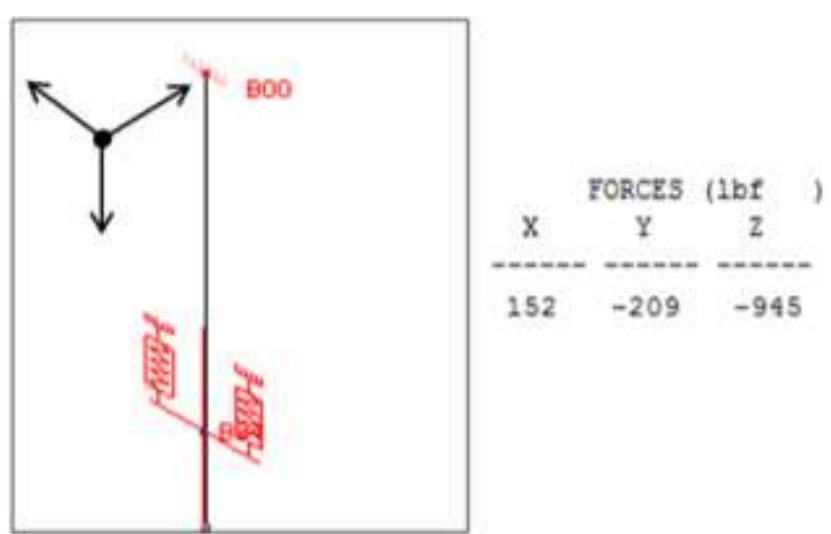

Fig. 14: Extraction Line MP Steam (force)
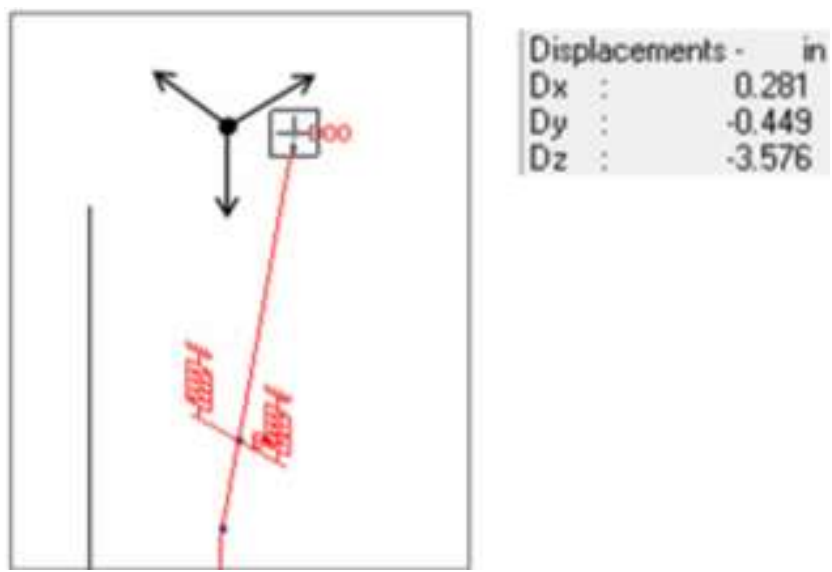

Fig. 15: Extraction Line MP Steam (displacements)

\section{Conclusion}

The misalignment hypothesis occurs because the shift of the turbine casing due to the load on the Inlet side, the outlet side or the result of both is not proven. The force acting on the Turbine Nozzle, the side of the HP Steam Inlet and MP Steam, is smaller than the weight of the Turbine casing. Misalignment is not caused by shifting the turbine casing.

Recommendation from the results of load analysis on the turbine casing, the misalignment is not caused by shifting the turbine casing. It is recommended that further research be carried out regarding the misalignment of the turbine shaft.

\section{References}

[1] American Society of Mechanical Engineers (ASME). (2010). ASME Code for Pressure Piping, B31: An American Nationa Standard-B31.1 - 2010 Power Piping. ASME.

[2] Bentley Systems Inc. (2011). AutoPIPE V8i (SELECTseries 3). https://communities.bentley.com/products/pipe stress analysis/f/au topipe-forum/72215/major-release---autopipe-v8i-selectseries-3v09-04-00-19-now-available-on-selectservices-online.

[3] Jung, J. ENTD, Turbin Operasional Problem. Course 234-Turbin and Auxiliaries, Module 234-14.

[4] Peng, L. C., \& Peng, T. L. (2009). Pipe stress engineering. ASME Press.

[5] Balaji, M. (2013). Optimization of piping layout with respect to pressure and temperature using CAESER-II. Mechanica Confab.

[6] Kannappan, S. (1986). Introduction to pipe stress analysis. John Wiley and Sons.

[7] Koorse, S., Roy, M., Janardhana, M., \& Seetharamu, S. (2014). An overview of stress analysis of high-energy pipeline systems used in thermal power plants. International Journal of Research in Engineering and Technology, 3(3), 538-542.

[8] Bhave, M. S. U. (2014). Calculation methodologies for the design of piping systems. International Journal of Engineering Research and General Science, 2(6), 596-603.

[9] American Society for Metals (ASM). (1986). Metals handbook. Vol. 11. Failure Analysis and Prevention. ASM. 